\title{
Metagenomic Analysis of Bacteria Phylum Firmicutes and Bacteroidetes in Women with Type 2 Diabetes
}

\author{
Zulhaerati, Sri Budiarti*, Rika Indri Astuti \\ Department of Biology, Faculty of Mathematics and Natural Sciences, Bogor Agricultural University, Bogor, Indonesia
}

\section{ARTICLE INFO}

Article history:

Received December 28, 2018

Received in revised form January 8, 2019

Accepted January 30, 2019

\section{KEYWORDS:}

Bacteroidetes,

Firmicutes,

metagenomic,

type 2 Diabetes

\begin{abstract}
Diabetes mellitus (DM) is a serious health problem in Indonesia. Type 2 diabetes is a metabolic disease which primarily caused by obesity-linked insulin resistance. There is a link between insulin resistance and bacterial populations in the gut. Therefore, the aims of this study was to analyze composition of bacteria belong to the phylum Firmicutes and Bacteroidetes in women with type 2 diabetes and nondiabetic persons as control. The study included five female adults type $\mathbf{2}$ diabetes patients and five healthy controls. The bacteria composition was analyzed for abundance by denaturing gradient gel electrophoresis (DGGE). Metagenomic analysis based on 16S rRNA gene was represented by 12 DGGE bands. The twelve respective bands showed the similarity ranging from 77 up to $98 \%$. Diversity of microbial composition in women type 2 diabetes was represented by five DGGE bands are Bacteroides fragilis, Bacteroides vulgatus, uncultured Bacteroides sp. clone Lb4eF4, uncultured bacterium clone 16sms90-5g05, and uncultured bacterium clone Malaga 1F14. Four DGGE bands in women healthy controls are closely related to uncultured bacterium isolate DGGE gel band Eub42, uncultured bacterium isolate DGGE gel band K115, uncultured bacterium clone HFV04255, and Enterococcus sp. the finding shows bacterial species belong to the phylum Bacteroidetes was mostly found in women diabetic group, while those belong to the phylum Firmicutes was mostly found in healthy controls.
\end{abstract}

\section{Introduction}

Diabetes mellitus (DM) is a serious world health problem. According to the data of International Diabetes Federation (2015), a number of DM cases in worldwide exceeds 415 million patients. This number is expected to increase 642 million patients in 2040. Indonesia ranks $7^{\text {th }}$ out of 10 countries with most DM contributors in the world. Data of KEMENKES (2013), the total of DM patients in Indonesia achieves 12 million people in 2013 and it will mount gradually. This disease actually is caused by an increase of glucose in blood that is impacted by an impaired insulin secretion. Furthermore, more than $90 \%$ of diabetes cases are DM type 2 (IDF 2015). Diabetes in this type is more in consequence of in effective insulin usage by the human body that is characterized by obesity (Harstra et al. 2015). Kootte et al. (2012) report that a composition change of microbiota diversity in the gut will lead to an

\footnotetext{
* Corresponding Author

E-mail Address: : s_budiarti@yahoo.com
}

unbalanced microbiota that triggers appearing some diseases, one of them is diabetes mellitus.

One of the metabolism changes is a Short Chain Fatty Acid (SCFA) fermentation such as butyrate, acetate, succinate, and propionate. The SCFA is able to be used for different tracks based on numbers and types of microbiota that are available in the intestines. A ratio between Bacteroidetes and Firmicutes will liven up in patients with DM type 2 which is positively correlated to decrease tolerance on glucose (Larsen et al. 2010). Certain bacteria species from phylum Firmicutes are able to produce butyrate for preserving intestinal epithelium that inflammation in the gut is avoided. The abundance of Bacteroidetes is highly related to decreasing body weight. The Firmicutes will drop into a hypocaloric condition that the Bacteroidetes is able to proliferate in the intestine. A high abundance of Bacteroidetes can convert lactate to become acetate, succinate, and propionate that are able to harm intestinal epithelium and trigger inflammation and resistance towards glucose where impacting to occur diabetes mellitus disease (Remely et al. 2013). 
Several pieces research have been conducted to analyze the diversity of intestinal microbiota that is contributed to the DM disease. However, a faced obstacle recently is an absence of a clear consensus relating to microbiota data. Microbiota growth in the intestine is highly affected by several factors namely genetic, diet, food type, and geographic (Kinross et al. 2011) where every individual has a different microbiota diversity. Based on a research that has been carried out by Wu et al. (2010) for six adult women of DM type 2 patients in China infer that the abundance of Bacteroidetes in DM patients (53.6\%) is higher than healthy people (11.8\%). Another research that has been conducted by Harstra et al. (2015) for women with DM type 2 in Sweden found that phylum Bacteroidetes decrease in the DM patients and the phylum Firmicutes increases. Metagenomic analysis of intestinal microbiota in women patients of DM type 2 is never been reported in Indonesia previously. Therefore, a study about the microbiota diversity is necessarily important to be carried out as an effort to analyze a mark of microbiota that is associated with DM type 2 disease events. Hence, this research was aimed to analyze composition of bacteria belong to the phylum Firmicutes and Bacteroidetes in women with type 2 diabetes and non-diabetic persons as control.

\section{Materials and Methods}

\subsection{Sample Collection}

Samples of feces were taken from a population that was consisted of 30 patients and 30 non-patients as respondents. Those respondents were delivered questionnaires to compile information related to several characteristics such as women with ages in range of 25 to 67 years old, willing to sign an informed consent letter, willing not to take antibiotic drugs for 6 months (Goossens et al. 2005) and no being suffered from diarrhea to avoid pathogenic bacteria in their feces. Patients of DM type 2 is characterized by an in the course of blood glucose rate in blood capillaries $\geq 200 \mathrm{mg} / \mathrm{dl}$ with body mass index (BMI) which is based on WHO (2018) namely less $\left(\leq 18.5 \mathrm{~kg} / \mathrm{m}^{2}\right)$, normal $\left(18.5-24.9 \mathrm{~kg} / \mathrm{m}^{2}\right)$, pre-obesity $\left(\geq 25 \mathrm{~kg} / \mathrm{m}^{2}\right)$, and obesity $\left(\geq 30 \mathrm{~kg} / \mathrm{m}^{2}\right)$. Determination of samples was based on the criteria above resulting five-woman respondents of patients with DM type 2 and fivewoman respondents of non-patients. Feces of those respondents were stored in closed sterile containers under $4^{\circ} \mathrm{C}$ condition and then they were conveyed to a laboratory for analyzing.

\subsection{DNA Extraction and Quantification}

An extraction of DNA from samples of feces was carried out by using a kit Zymobiomics ${ }^{\mathrm{TM}}$ DNA Miniprep Kit (USA). Concentration and DNA purification were then analyzed by using a NanoDrop 2000 (Thermo Scientific, Wilmington, DE, USA).

\subsection{PCR Amplification of $16 \mathrm{~S}$ rRNA Gene}

Amplification step was executed by using a Polymerase Chain Reaction (PCR) method with T1-thermocycler (Biometra, Goettingen Germany). The used primers were P338F-GC (5'-CGCCCGCCGCGCGCGGCGGGCGGGGCGGGGGCAC GGGGGGACTCCTACGGGAGGCAGCAG-3') and P518R (5'-ATTACCGCGGCTGCTGG-3') (Overeas et al. 1997). Amplification was taken by utilizing a GoTaq Green Mastermix 2x (Promega, Madison, USA), with a composition of PCR as follows $12.5 \mu$ of Gotaq Green Promega, two primers (P338F and P518R were $2.5 \mu \mathrm{l}$, DNA template $0.5 \mu \mathrm{l}(21 \mathrm{ng} / \mu \mathrm{l})$, respectively) and an additional nuclease-free water until the final volume exceeded $30 \mu \mathrm{l}$. The PCR was conditioned for several treatments such as pre-denaturation under $94^{\circ} \mathrm{C}$ for 5 minutes, denaturation under $94^{\circ} \mathrm{C}$ for 30 seconds, annealing under $55^{\circ} \mathrm{C}$ for 30 seconds, elongation under $72^{\circ} \mathrm{C}$ for 30 seconds as many as 30 cycles. Results of the PCR then were electrophoresed in 1.5\% agarose gel and furthermore were documented in a G:BOX (Syngenee Frederick, MD, USA).

\subsection{DGGE Analysis of the $16 S$ rRNA Gene}

The resulted PCR of gene 16S rRNA was migrated into an $8 \%(\mathrm{w} / \mathrm{v})$ polyacrylamide gel that was created from acrylamide-bisacrylamide [37.5:1] in 1x Trisasetate-EDTA (TAE). The gradient of denaturant was set between 35 to $65 \%$ and the denaturant becoming $100 \%$ was formulated by adding $7 \mathrm{M}$ of urea and $40 \%$ $(\mathrm{v} / \mathrm{v})$ of formamide. The electrophoresis process was conditioned under temperature $60^{\circ} \mathrm{C}$ and voltages 60 Volt as long as 15 hours by using a $D$ Code Universal Mutation Detection System (Bio-Rad, Hercules, CA, USA). Visualization of the resulted process was documented by using a G:BOX (Syngenee, Frederick, MD, USA). The resulted photo of gel doc was then analyzed by a Labimage ID software. The separated DNA band was cut by using a sterile scalpel knife and put in a tube containing a 


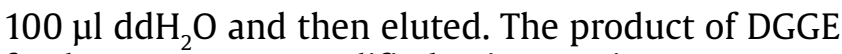
furthermore was amplified using a primer gene 16S rRNA without using a GC-clamp (Muyzer et al. 1993).

\subsection{S rRNA Gene Sequencing, Bioinformatics Analysis, and Phylogeneetic Tree Construction}

The cut gel containing eluted DNA band was then amplified again with the DNA which was functioned as a template. Amount of $50 \mathrm{ng}$ of DNA was amplified by using a specific primer P338F/P518R without GC clamps. The successful amplified DNAs were then sent to a Sequencing Service Company (Macrogene Korea) for sequencing process. The sequenced DNAs were analyzed using a ChromasPro software (Technelysium, AU) for assembling process and trimming. Homology analysis was administered by comparing sequenced DGGE bands with a gene bank database through a software of Basic Local Alignment Search Tool Nucleotide (BLAST-N) (www. blast.ncbi.nlm.nih.gov). The gained homolog sequences were further aligned by using a MEGA 6.0 software (Tamura et al. 2013) with a Neighbor-Joining Method. A clustering analysis was taken based on the profile of DGGE that had been interpreted by using Labimage ID and PAST 3 software.

\subsection{Ethical Considerations}

The research protocol was approved by the Ethics Committee of the Faculty of Medicine, the University of Indonesia (No:17-08-0788).

\section{Results}

\subsection{Respondent Characteristics}

Respondents consisted of two groups namely DM type 2 patients and non-patients as the control. The population of this research was students and housewives who are living in around Babakan Raya, Dramaga, Bogor, West Java. Those respondents were categorized according to Body Mass Index (BMI) which patients and non-patients, pre-obesity, and obesity, were 7 persons, 1 person, and 2 persons, respectively (Table 1). Eating habit of patients (P1-P5) in consuming foodsis more similar with less time intensity per day than non-patients (C1-C5). The eating habits of control in consuming foods is more varied with more time intensity per day.

\subsection{Analysis of Gene 16S rRNA in Feces Samples}

Amplification of gene 16S rRNA in feces sample used a universal primer of bacteria namely P338F/ P518R that specifically amplified V3 region in 16S rRNA. There were 10 samples that had been amplified and generatea single band. The product of PCR gene 16S rRNA of bacteria in feces sample was analyzed by using a nested PCR technique. This technique applies two times of PCR. The first and second steps of PCR exhibit a proper amplicon size with the allowed fragment size namely $\pm 200 \mathrm{pb}$ (Figure 1 ).

\subsection{Metagenomic Analysis of Bacteria Community}

This research used a non-culture approach (metagenomic) with DGGE technique. Based on the band distribution pattern of polyacrylamide gel, the community of feces bacteria of control is in range of 15 bands at sample $\mathrm{K} 1$ to 22 bands at sample K3. This result is more uniform than the patients of DM type 2 that is in range of 14 bands at sample P5 to 18 bands at sample P3 (Figure 2). Direct observation and position consideration of resulted DGGE bands point out that there are three DGGE bands which always appear for all samples (band $4,9,10$ ), and five bands are only found in samples of patients (band 2, 5, 7, 8, 12), and four bands which are only discovered in samples of control (band 1, 3, 6, 11). Those twelve separated bands are successfully isolated through gel cut for further sequencing analysis of their DNA.

Table1. Characteristics of patients and non-patients of DM type 2

\begin{tabular}{|c|c|c|c|c|c|c|c|c|c|}
\hline \multirow[b]{2}{*}{ Sample } & \multirow[b]{2}{*}{$\begin{array}{l}\text { Age } \\
\text { (year) }\end{array}$} & \multirow[b]{2}{*}{$\begin{array}{c}\text { BMI } \\
\left(\mathrm{kg} / \mathrm{m}^{2}\right)\end{array}$} & \multirow[b]{2}{*}{$\begin{array}{l}\text { RBG } \\
(\mathrm{mg} / \mathrm{dl})\end{array}$} & \multicolumn{5}{|c|}{ Eating habits } & \multirow[b]{2}{*}{ Information } \\
\hline & & & & $\begin{array}{l}\text { Consuming } \\
\text { staple foods } \\
\text { (time/day) }\end{array}$ & $\begin{array}{l}\text { Consuming } \\
\text { vegetable } \\
\text { (time/day) }\end{array}$ & $\begin{array}{l}\text { Consuming } \\
\text { fruits } \\
\text { (time/day) }\end{array}$ & $\begin{array}{l}\text { Consuming } \\
\text { snack } \\
\text { (yes or not) }\end{array}$ & $\begin{array}{l}\text { Consuming } \\
\text { fast food } \\
\text { (yes or not) }\end{array}$ & \\
\hline P1 & 53 & 18.8 & 407 & 2 & 1 & 1 & Not & Not & Sick \\
\hline P2 & 67 & 28.6 & 243 & 1 & 2 & 1 & Not & Not & Sick \\
\hline P3 & 62 & 30.0 & 263 & 1 & 1 & 1 & Not & Not & Sick \\
\hline P4 & 57 & 31.0 & 210 & 2 & 1 & 1 & Not & Not & Sick \\
\hline P5 & 47 & 22.1 & 400 & 1 & 1 & 1 & Not & Not & Sick \\
\hline K1 & 25 & 20.3 & 77 & 3 & 3 & 2 & Yes & Yes & Healthy \\
\hline $\mathrm{K} 2$ & 25 & 23.6 & 90 & 3 & 3 & 3 & Yes & Yes & Healthy \\
\hline K3 & 26 & 23.1 & 85 & 3 & 3 & 3 & Yes & Not & Healthy \\
\hline K4 & 47 & 22.1 & 101 & 3 & 2 & 2 & Yes & Yes & Healthy \\
\hline K5 & 30 & 22.4 & 88 & 3 & 3 & 2 & Yes & Not & Healthy \\
\hline
\end{tabular}

Abbreviation: $\mathrm{p}$ = patient, $\mathrm{k}=$ control (non-patient), $\mathrm{BMI}=$ body mass index, $\mathrm{RBG}$ = random blood glucose 


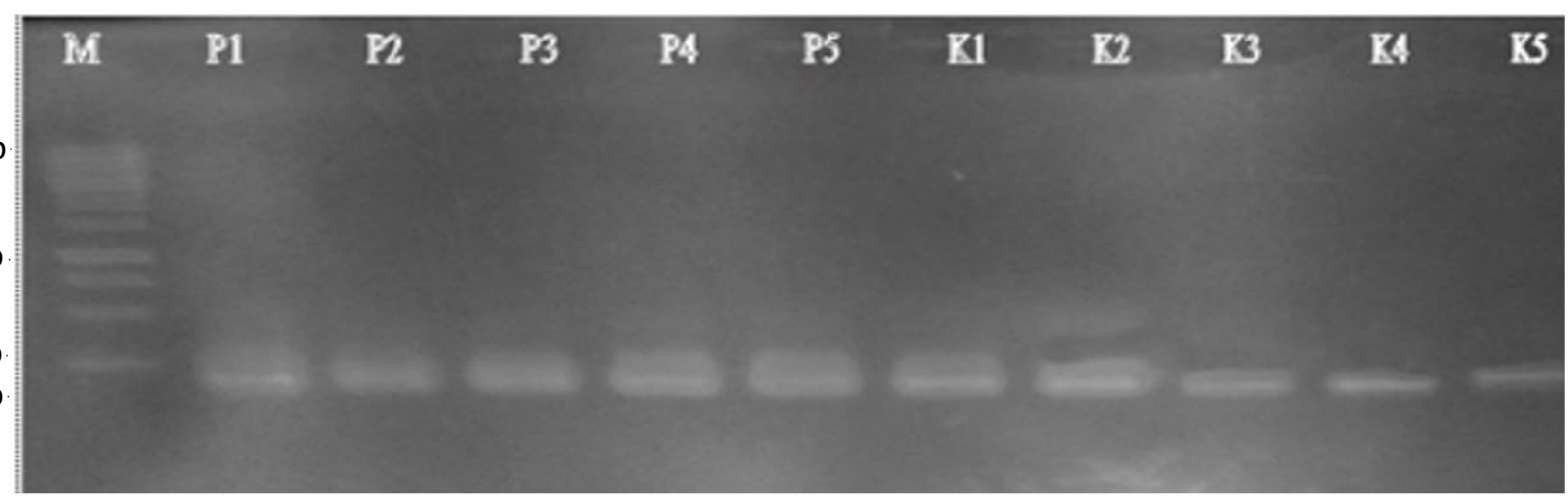

Figure 1. Visualization of resulted DNA amplification of gene 16S RNA in agarose 1.5\%, M=a mark of DNA molecule; P1, P2, P3, P4, P5: feces samples of DM type 2 patients; K1, K2, K3, K4, K5: feces sample of healty respondent as control

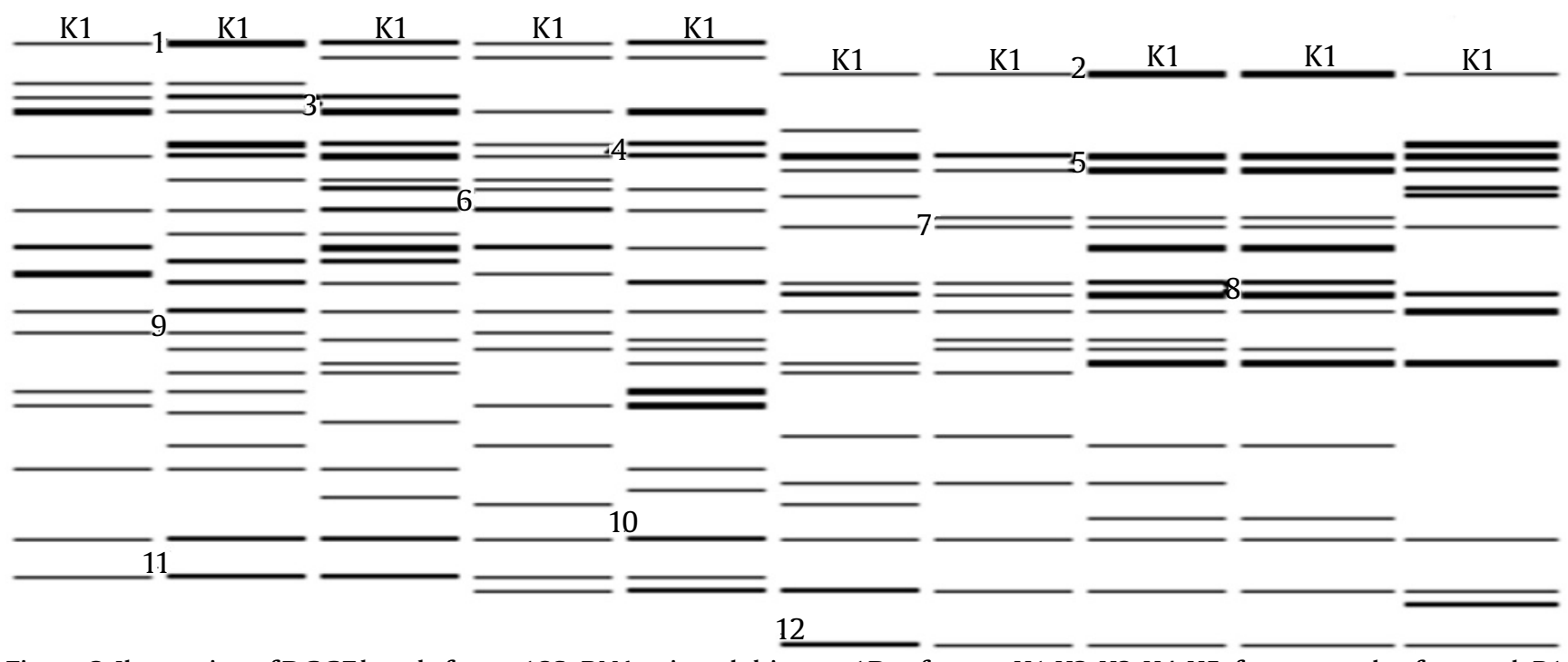

Figure 2.Ilustration ofDGGEband of gene 16SrRNAusing a labimage 1D software. K1,K2,K3, K4, K5: feces sample of control; P1, P2,P3,P4,P5: feces sample of patients with DM type2. The sequential numbers exhibit bands that were cut for re-PCR

A diversity analysis of Shannon-Wienner Index $\left(\mathrm{H}^{\prime}\right)$ was used to estimate bacterial diversity in each sample in both DM type 2 patients and normal respondents. The estimation results signify that the Shannon-Wienner Index $\left(\mathrm{H}^{\prime}\right)$ commonly community of bacterial feces of control based on gene 16S rRNA is in range of 2,6242,997 , while DM type 2 patients are in range of 2,4762,829 . Furthermore, the evenness index ( $e^{\prime}$ ) is in range of 0.8422-0.9604 that is categorized into high category. A high category of this index is where e'>0.6 (Figure 3 ).

The advanced analysis is a sequential analysis where used a Chromas Pro software. Alignment result of nucleotide shows that nine bands of DGGE are majority identified as an uncultured bacterium, however, three bands of the identified DGGE are Bacteroides vulgatus, Bacteroides fragilis, and Enterococcus sp. (Table 2). In

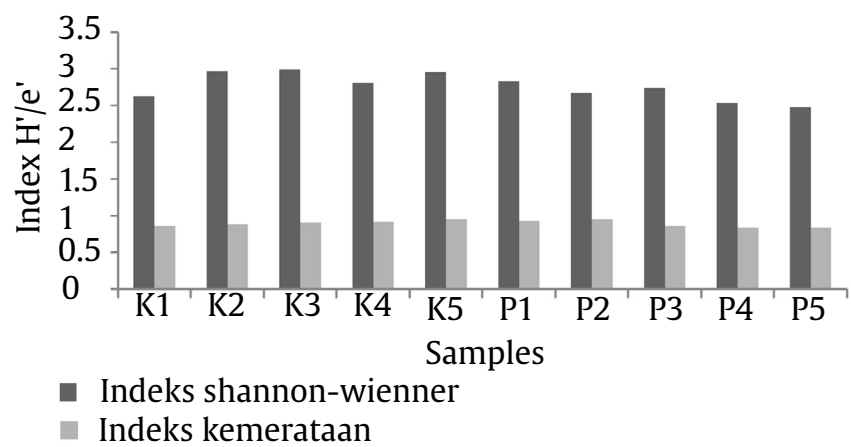

Figure 3. Diversity index of shannon-wiennerand everness index of bacterial community based on gene $16 \mathrm{~S}$ rRNA in 10 feces samples. K1, K2, K3, K4, K5: feces samples of control; P1, P2, P3, P4, P5: feces samples of DM type 2 patients 
commonly, a percentage of sequence similarity of the resulted DGGE with database genebank target is about $77-98 \%$. Based on the phylogenetic analysis of gene $16 \mathrm{~S}$ rRNA, grouping types of bacteria arein according with their phylum. The phylogenetic tree is constructed by a neighbor-joining tree model namely Kimura 2-parameter model with bootstrap 2000x (Figure 4).

Table 2. Homology analysis of bacteria metagenome based on 16S rRNA sequence

\begin{tabular}{|c|c|c|c|c|c|c|}
\hline Band & Description & $\begin{array}{l}\text { Query cover } \\
(\%)\end{array}$ & E-value & $\begin{array}{c}\text { Identity } \\
(\%)\end{array}$ & No. access & Phylum \\
\hline 1 & $\begin{array}{l}\text { Uncultured bacterium isolate } \\
\text { DGGE gel band Eub_42 }\end{array}$ & 85 & $3 e-69$ & 93 & GQ411146 & Firmicutes \\
\hline 2 & $\begin{array}{l}\text { Bacteroides fragilis strain } \\
\text { DBT194 }\end{array}$ & 100 & $3 e-79$ & 95 & MH482986 & Bacteroidetes \\
\hline 3 & $\begin{array}{l}\text { Uncultured bacterium isolate } \\
\text { DGGE gel band } \mathrm{K} 1-15\end{array}$ & 100 & $1 \mathrm{e}-81$ & 99 & KF880980 & Firmicutes \\
\hline 4 & $\begin{array}{l}\text { Uncultured Bacteroidetes } \\
\text { bacterium clone SS37 }\end{array}$ & 100 & $6 e-86$ & 97 & HM442603 & Bacteroidetes \\
\hline 5 & $\begin{array}{l}\text { Bacteroides vulgatus strain } \\
\text { DNF00399 }\end{array}$ & 100 & $6 e-91$ & 99 & KU726654 & Bacteroidetes \\
\hline 6 & $\begin{array}{l}\text { Uncultured bacterium clone } \\
\text { HFV04_255 }\end{array}$ & 54 & $1 \mathrm{e}-22$ & 89 & GU105100 & Firmicutes \\
\hline 7 & $\begin{array}{l}\text { Uncultured Bacteroides sp. clone } \\
\text { Grap1_Lb4e_F4 }\end{array}$ & 100 & $4 e-73$ & 93 & KP716770 & Bacteroidetes \\
\hline 8 & $\begin{array}{l}\text { Uncultured bacterium clone } \\
16 \text { sms90-5g05 }\end{array}$ & 100 & $4 e-72$ & 97 & JF259225 & Firmicutes \\
\hline 9 & $\begin{array}{l}\text { Uncultured bacterium clone } \\
\text { nbw79c03c1 }\end{array}$ & 100 & $7 e-10$ & 76 & GQ064768 & Firmicutes \\
\hline 10 & $\begin{array}{l}\text { Uncultured bacterium clone } \\
\text { LN07 }\end{array}$ & 100 & $1 e-32$ & 81 & AY980738 & Bacteroidetes \\
\hline 11 & Enterococcus sp. strain C12 & 100 & 1e-93 & 99 & MH754157 & Firmicutes \\
\hline 12 & $\begin{array}{l}\text { Uncultured bacterium clone } \\
\text { G02_2_2a5_Malaga_1F_14 }\end{array}$ & 77 & $7 e-30$ & 87 & FJ345877 & Bacteroidetes \\
\hline
\end{tabular}

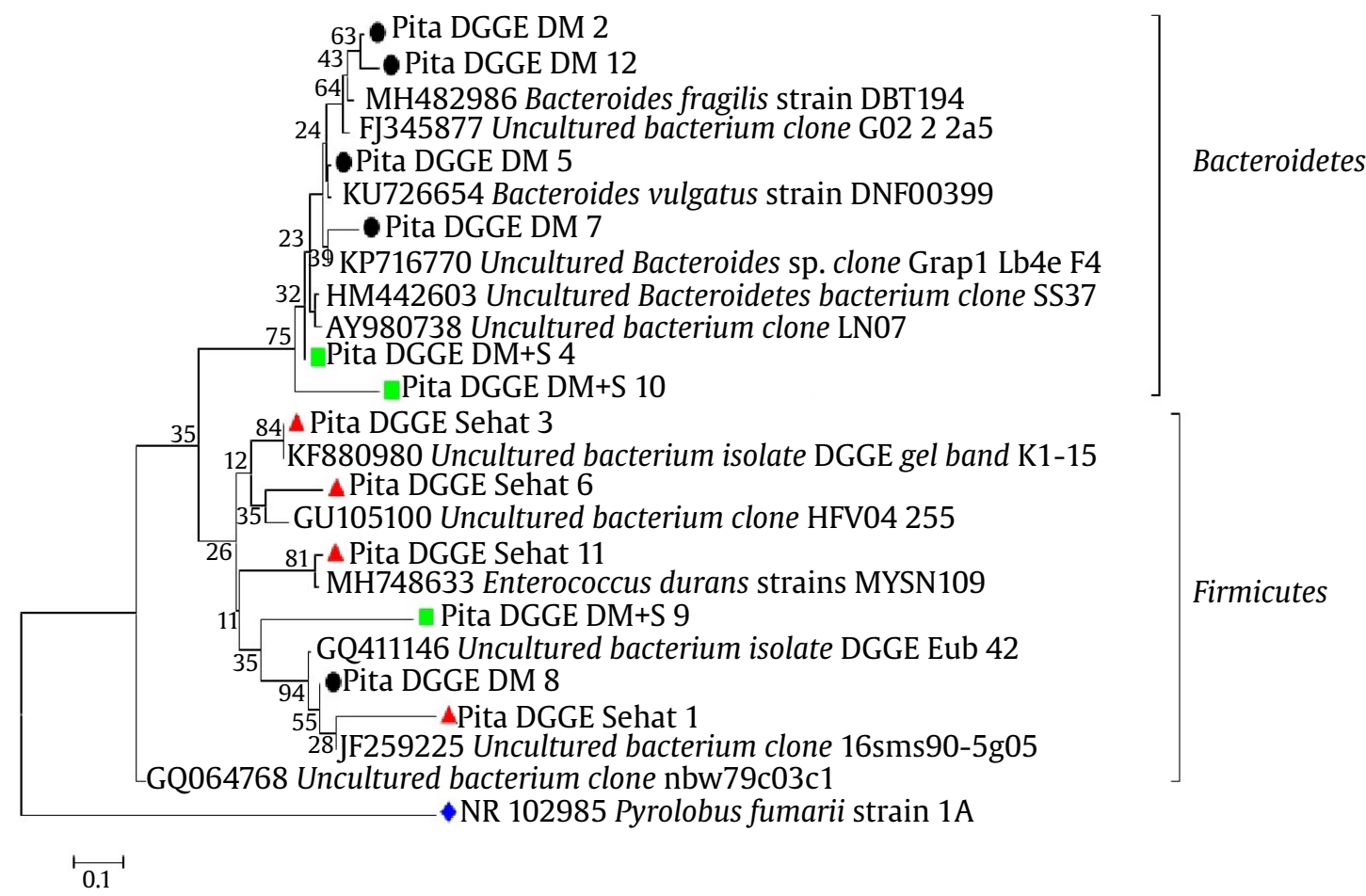

Figure 4. Phylogenetic tree (neighbor joining tree) of 16S rRNA using Jukes Cantor model with boostrap 2000x. Sequential numbers indicate sequented bands 


\section{Discussion}

Respondents in this research are women. Yulianti et al. (2014) report that prevalence of women who are suffered from diabetes mellitus is higher than men due to their activities is less to produce energy. The gene $16 \mathrm{~S}$ rRNA of feces samples were analyzed by using a universal primer namely P338F/P518R (Overeas et al. 1997). This primer is designed to amplify all regions of $\mathrm{V} 3$ in 16S rRNA. The Gene 16S rRNA has nine hypervariable regions (V1-V9). These regions are very effective for designing a mark in identifying bacteria. In geneeral, regions V2 and V3 are very appropriate in distinguishing a various type of bacteria in geneus level. The region $\mathrm{V} 2$ has a long alkalinity of 106 nucleotides, while V3 only has 65 nucleotides (Chakravorty et al. 2007). In this research, the region V3 was used due to it is able to provide phylogenetic information adequately about bacteria that are presented in a sample (Huse et al. 2008).

Based on a melting pattern that is caused by denaturant gradient in a polyacrylamide gel, the DNA fragment with different sequence will migrate with a different position that yield a band pattern which represent a different taxon. According to Crosby and Criddle (2003), DGGE is able to distinguish a sequence of species based on a differentiation of melting temperature (Tm) in a DNA. Melting temperature in a DNA sequence is affected by G-C alkaline compound in DNA (Muyzer et al. 1993). Metagenomic approach with DGGE has several advantages such as more efficient, quick, and a good result to compare diversity structure of a total community of microbiota (Fuji et al. 2006). Therefore, the DGGE technique is able to differentiate species based on GC composition of analyzed sequence in the analysis (Overeas et al. 1997). In this research, not all bands were cut and sequenced. Band selection in all samples were aimed to seek a more dominant bacteria. While the band was only found in the DM patients or only in the control (non-patients) that can be used for a mark of intestinal microbiota that are associated with metabolism process of health people and DM type 2 patients.

Results of analyzing Shannon-Wienner $\left(\mathrm{H}^{\prime}\right)$ indicates that feces samples of control have more diversity and varied of Operational Taxonomic Unit (OTU) than the diversity of OUT in feces samples of DM type 2 patients. However, overall diversity category of those sample feces was appertained into medium with Shannon index among $1>\mathrm{H}>3$.5. The similar result also has been reported by $\mathrm{Wu}$ et al.(2010) that there is no difference of Shannon-Wienner
Index $\left(\mathrm{H}^{\prime}\right)$ for feces bacteria community of control and DM type 2 patients within averaged of 0.94 which is included low category. The current research also points out that the evenness index ( $e^{\prime}$ ) of all feces samples for both control and patients is similar each other.

Furthermore, band 1 (Uncultured Roseburia sp. clone QY27 is found in control and band 5 (Bacteroides vulgatus strain NMBE-5) was in DM type 2 patients are unique bands that have the highest abundance. These both bands are able to be presumed as marks for intestinal microbiota that are associated with metabolism process in both control and patients of DM type 2. Roseburia sp. is a member of phylum Firmicutes, while B. vulgatus is a member of phylum Bacteroidetes. Both phyla are bacterial phylum that present in gut dominantly (Gill et al. 2006). In general, sequenced bands for DM type 2 patients come from phylum Bacteoridetes, and conversely, phylum Firmicutes is commonly for control or healthy people. Larsen et al. (2010) have reported that the abundance Firmicutes is higher in healthy people than DM type 2 patients.

Harstra et al. (2015) reported that Roseburia sp. is a type of bacteria that produce butyrate for preserving intestinal epithelium toward inflammation. The inflammation is able to disturb insulin signaling, that insulin is able to work maximally in controlling blood glucose for keeping normal. In another hand, $B$. vulgatus is able to change lactate in guts to become succinate, acetate, and propionate that can cause a disruption of intestinal permeability (MejiaLeon and Calderon de la Barca 2015). This matter causes alipopolysaccharide (LPS) composing cell wall of gramnegative bacteria that should be in alimentary canals entering blood circulation and triggering an inflammation. This condition is able to activate Toll-like receptor (TLR) where the inflammation mediator like inhibitor NF-KB kinase (IKK) in metabolism track will inhibit signaling of insulin. It is impacted to targeted cells of insulin will be failed or unable to respond to insulin normally that the glucose rate is high in the blood (Wellen dan Hotamisligil 2005).

\section{Acknowledgments}

Authors thank Indonesian Endowment Fund for Education (LPDP) that had financed first authors study in IPB and sponsored this research. Gratefulness also is delivered to dr. Katili Clinic in Dramaga, Bogor, and respondents who had contributed to this research. 


\section{References}

Chakravorty S et al. 2007. A detailed analysis of $16 \mathrm{~S}$ ribosomal RNA gene segments for the diagnosis of pathogenic bacteria. J Microbiol Methods 69:330339.

Crosby LD, Criddle CS. 2003. Understanding bias in microbial community analysis techniques due to $\mathrm{rrn}$ operon copy number heterogeneit. Biotechniques 34:790-798.

Fuji T et al. 2006. Metagenomic Approach to Soil Microbial Diversity and Functions. Nanjing: Institut of Soil Science, Chinese Academy of Sciences.

Gill SR et al. 2006. Metagenomic analysis of the human distal gut microbiome. Science 312:1355-1359.

Goossens $\mathrm{H}$ et al. 2005. Out patient antibiotic use in Europe and association with resistance: a cross-national database study. The Lancet 365:579-587.

Hartstra AV et al. 2015. Insights into the role of the microbiome in obesity and type 2 diabetes. Diabetes Care 38:159-165.

Huse SM et al. 2008. Exploring microbial diversity and taxonomy using SSU rRNA hypervariable tag sequencing. PloS Genet 4:1-10.

[IDF] International Diabetes Federation. 2015. IDF Diabetes Atlas. $6^{\text {th }}$ ed. Brussels: IDF Publishing.

[KEMENKES] Kementerian Kesehatan Riset Kesehatan Dasar. 2013. Riset Kesehatan Dasar. Jakarta: Badan Litbangkes, Depkes RI.

Kinross JM et al. 2011. Gut microbiome-host interactions in health and disease. Genome Med 3:1-12.

Kootte RS et al. 2012. The therapeutic potential of manipulating gut microbiota in obesity and type 2 diabetes mellitus. Diabetes Obes Metab 14:112-120.
Larsen $\mathrm{N}$ et al. 2010. Gut microbiota in human adults with type 2 diabetes differs from non-diabetic adults. PLoS One 5:1-10.

Mejia-Leon ME, Calderon de la Barca AM. 2015. Diet, microbiota and immune system in type 1 diabetes development and evolution. Nutrients 7:9171-9184.

Muyzer G et al. 1993. Profiling of complex microbial populations by denaturing gradient gel electrophoresis analysis of polymerase chain reaction-amplified genes coding for 16S rRNA. Appl Environ Microbiol 59:695-700.

Overeas L et al. 1997. Distribution of bacterioplankton in meromictic lake saelenvannet, as determined by denaturing gradient gel electrophoresis of PCR amplified gene fragments coding for 16S rRNA. Appl Environ Microbiol 63:3367-3373.

Remely $\mathrm{M}$ et al. 2013. Abundance and diversity of microbiota in type 2 diabetes and obesity. J Diabetes Metab 4:1-8.

Tamura K et al. 2013. MEGA6: Moleculer evolutionary genetics analysis version 6.0. Mol Biol Evol 30:27252729.

Wellen KE, Hotamisligil GS. 2005. Inflammation, stress and diabetes. J Clin Invest 115:1111-1119.

Wu X et al. 2010. Molecular characterisation of the faecal microbiota in patients with type II diabetes. Curr Microbiol 61:69-78.

Yulianti SR et al. 2014. Profil pengobatan pasien diabetes mellitus tipe 2 di instalasi rawat inap RSUD Undata Palu tahun 2012. J Nat Sci 3:40-46.

[WHO] World Health Organization. 2018. Obesity and overweight. Fact sheet No. 311. Available at: http:// www.who.int/mediacentre/factsheets/fs311/en/ index.html [Data accessed 16 July 2018] 